\title{
Acerca do Feminino em $O$ Conto da Ilha Desconhecida, de José Saramago
}

\author{
Pedro Fernandes de Oliveira Neto*
}

Resumo: Da teia de discursos e preocupações temáticas entrelaçadas que se desfia na escrita saramaguiana podemos destacar "o papel de primordial importância concedido à mulher quer no que se refere ao histórico-social quer no que se refere ao relevo que desempenhará na (in) formação e desenvolvimento afetivo, moral e ideológico do universo masculino." (ARNAUT, 2007, p.3) Partindo deste pressuposto e da própria matéria narrativa que compõe o universo fictício do escritor português, buscaremos bases em $O$ conto da ilha desconhecida para ler as dimensões e as tessituras que compõem o feminino no ínterim deste texto.

Palavras-chave: literatura; feminino; Saramago.

\begin{abstract}
Of the tissue of speeches and thematic concerns interlaced that is unraveled in the writing of the Saramago we can detach "o papel de primordial importância concedido à mulher quer no que se refere ao histórico-social quer no que se refere ao relevo que desempenhará na (in) formação e desenvolvimento afetivo, moral e ideológico do universo masculino". (ARNAUT, 2007, p.3) Leaving of this presupposition and of the own narrative matter that composes the Portuguese writer's fictitious universe we will look for bases in $O$ conto da ilha desconhecida to read the dimensions that it composes the feminine in the interim of this text.
\end{abstract}

Keywords: literature; feminine; Saramago.

\section{Considerações iniciais}

Toda mulher é Eva. José Saramago, $O$ ano e a morte de Ricardo Reis

José Saramago constitui-se num escritor de múltiplas escritas. A sua literatura é como que uma espécie de linha que se desfia no tempo (passado-presente-futuro) e este tempo é impresso por um corredor de vozes tecendo-se como uma espécie de teia cruzada e recruzada; uma literatura em que discursos e temas se entrelaçam a tal ponto que um ordenamento simplesmente cronológico ou quantitativo não nos é suficiente para dar conta de determinados aspectos. Além de que, englobar perspectivas também é um sintoma ingênuo para com a obra deste escritor porque fere o que há de humano no território de sua escrita e engessa o objeto artístico despindo-o de sua significância. Assim, nossa tarefa para com este texto é a de

\footnotetext{
* Mestrando do PPGL da Universidade do Estado do Rio Grande do Norte (UERN).
} 
estabelecer linhas ou simplesmente dispor idéias a título de tornar a leitura do objeto literário em questão, O conto da ilha desconhecida (1997) mais palpável do jogo definido/in-definido que nele se abre. Sendo um exercício de leitura o que nos propomos a realizar, seguimos o movimento do próprio tecido narrativo, preenchendo as frestas dos fios que o compõe.

A obra vasta de Saramago, entretanto, não se marca apenas pela dimensão da produção escrita, mas também pelas vastas questões que os seus textos suscitam. Dentre estas grandes preocupações que se traçam no texto saramaguiano, cite-se algumas, tais como: (i) a descrença desmedida na figura divina e consequentemente no papel da igreja e da religião na sociedade ou ainda (ii) as reflexões em torno do poder e das ideologias que moldam os espaços sociais contemporâneos (cf. ARNAUT, 2007, p.2).

No universo destas grandes preocupações temáticas expostas no autor luso podemos ainda destacar, quando para dentro delas nos movemos, o rumor de outras presenças discursivas. Ignorá-las seria um erro terrível. Que se cite no ínterim de sua obra "o papel de primordial importância concedido à mulher quer no que se refere ao histórico-social quer no que se refere ao relevo que desempenhará na (in) formação e desenvolvimento afetivo, moral e ideológico do universo masculino.” (ARNAUT, 2007, p.3). Partindo deste pressuposto teórico e da própria matéria narrativa que compõe o universo fictício do escritor português buscaremos bases em $O$ conto da ilha desconhecida para ler estas dimensões e estas tessituras que compõem a imagem do feminino no ínterim deste texto.

\section{Acerca do feminino na obra de José Saramago}

Quando se fala da questão feminina, uma afirmação já se tornou clichê contemporaneamente. Recobramos este clichê para dele desencadearmos esta leitura. A afirmação é a de que a mulher tem sido milenarmente oprimida e cerceada em todos os espaços. Ao reportamos o espaço literário ela tem assumido, além desta face social, outras faces: sejam as de anjo-demônio, sejam as de musa inspiradora. Contudo, quando nos voltamos para o universo fictício da narrativa saramaguiana, ambos os papéis femininos parecem sofrer uma inversão e, logo em seguida, uma dilatação, tornando-se a mulher importante não apenas quantitativamente, mas também no desempenho de funções nos corpos de seus romances, como a condução da diegese.

Em nenhuma de suas obras, conforme o escritor, ele perde o respeito ao gênero feminino em geral; às personagens femininas, em particular, assentam certa notoriedade. Entretanto, certos lugares-comuns que a literatura delegou à mulher, como o eterno feminino 
ou sonho inspirador, o que para ele se constituem mais reflexos marianos, não se marcam na composição de suas personagens: "Na verdade, as mulheres são muito mais sensatas: nunca fizeram do homem um 'sonho inspirador' nem falaram do 'eterno masculino'." (SARAMAGO, 1998, p.240). Parafraseando o próprio Saramago, também não as considera, tanto as de carne e osso como as que vão aparecendo nas histórias que conta, símbolo/objeto de veneração, no sentido quase religioso em que a palavra muitas vezes é usada.

Logo, as mulheres no decurso da ficção saramaguiana se portam nas linhas que as delimitam enquanto simples humanas. Tal acontece quando reportamos o universo romanesco que o escritor vai moldando, cujos aspectos e a importância dada ao feminino se manifestam amalgamados em diferentes extensões e se prolongam diversamente.

Inserindo-se naquela primeira preocupação temática, a da descrença desmedida na figura do divino e consequentemente no papel da igreja e da religião na sociedade, entre tantas outras personagens femininas de José Saramago, citemos Leonor, de seu primeiro romance, Terra do pecado (1947); Blimunda, de Memorial do convento (1982); e, Maria de Magdala d'O evangelho segundo Jesus Cristo (1991). Todas elas se movem nas malhas da narrativa como a Eva do Gênesis cristão, no entanto, ressignificadas, não comportando em si o sentido de pecadora que a exegese cristã conserva, mas sim um caráter de desobediência humana necessária àquilo que é proibido, não aceitando o já-dito, rompendo com a ordem estabelecida; todas usadas pelo autor como questionadoras do divino. Estas mulheres se marcam por, no decorrer das malhas textuais, ao romperem com o sagrado, desestruturá-lo ou (re) moldá-lo ao seu modo, emprestando-lhes novas feições, mais coerentes em si. São mulheres habilidosas, curiosas, transgressoras, mas elas não encerram em si, por parte do narrador, a imagem de pecadora ou de veneradas, no sentido religioso; ao mesmo tempo são peças importantes, molas propulsoras à condução e concreção do fio narrativo.

Destaque seja feito para a primeira, Leonor, que no ínterim de seu desafio para com a moralidade cristã será maculada pelo sêmen de dois outros homens que não o do seu 'verdadeiro'; isso pelo simples prazer. A marca de humanidade que esta figura comportará será a do autocastramento psíquico e físico por ainda não se ver no papel liberal a ela incumbido. Ou ainda, para a terceira, Maria de Magdala, responsável pelo caráter de um Jesus enquanto homem, ativo sexualmente, quebrando o caráter linear e superficial que o discurso cristão o faz de divino, levando-o a como um humano ao amor e ao erro.

De Blimunda, além desse papel de transgressora ela comporta em si uma capacidade extraordinária de ver o que realmente há no mundo. Essa visão aguçada da personagem é a que dá visão ao próprio narrador, atuando, pois, num processo invertido. Blimunda é a que 
mostra os excessos da nobreza, o alto investimento de D João para construir o Convento de Mafra, os atos da Inquisição beneficentes aos interesses da Coroa portuguesa, isto é, a real imagem de uma sociedade que se escondia nas suas fragilidades. Sem falar de seu poder de ajudar à construção da Passarola; poder que, em Levantado do chão (1980), faz Faustina ou Gracinda Mau-Tempo, companheira de vida e de armas de homens no Alentejo na luta contra o latifúndio e os poderes instituídos.

Em História do cerco de Lisboa (1989), Maria Sara é o fator-causa que leva Raimundo à reescrita da História do cerco de Lisboa. Cabe a ela enquanto 'Eva' o desenvolvimento da individualidade, da afetividade e das capacidades crítico-intelectuais do sexo masculino.

No que tange ao segundo fio de preocupação temática da obra saramaguiana, que é aquele das reflexões em torno do poder e das ideologias que moldam os espaços sociais contemporâneos, citemos a mulher do médico, do Ensaio sobre a cegueira (1995) e do Ensaio sobre a lucidez (2004), romance em que ela retorna. Ou a figura icônica de Todos os nomes (1997); Maria Isasca ou Isaura Madruga do romance A caverna (2001); ou, ainda, a própria figura da Morte em As intermitências da morte (2005).

No primeiro e no segundo romance, Ensaio sobre a cegueira e Ensaio sobre a lucidez respectivamente, é a mulher do médico que, semelhante à Blimunda de Memorial do convento, é a única personagem a conservar, ao longo da primeira narrativa, a capacidade de olhar, de ver e de compreender as competências do poder. No primeiro Ensaio, cabe à mulher do médico o papel de condutora da narrativa, sendo a que participa ativamente do conflito dramático. Enquanto mulher, é a ela delegado o papel de "mater dolorosa" (cf. SEIXO, 1996, p.201) - “Sou a que nasceu para ver o horror” (SARAMAGO, 1995, p.262) - dando conta da solidão do ser quando ela torna-se sujeito excepcional à situação de total cegueira, recobrando o caráter do autor português para com o feminino: o de ser a mulher um ser bussolar, de apoio e de resistência. Ainda que todos os personagens participem do conflito, ela é a única que possui a visão do caos em que se transforma a convivência humana ao longo do estágio da cegueira branca, bem como é pelas suas ações e reflexões que a obra saramaguiana incute a crítica ao aparelho social e ao comodismo e dependência do homem a tal aparelho.

Em Todos os nomes é a mulher "a mentora indireta da revitalização anímica de José" (ARNAUT, 2007, p.4). É a partir dela que ele recobra o sentido da vida enquanto se achava preso à monotonia de seu trabalho; este papel também será cabido às personagens femininas d'A caverna, Maria Isasca ou Isaura Madruga, sendo cada uma delas ao seu modo as que trazem o sopro e o acalanto à vida de Cipriano Algor. 
Mas talvez a maior significação do feminino no corpo do romance saramaguiano venha a se constituir no ínterim do romance As intermitências da morte (2005). Ao colocar o símbolo maior sobre a vida, a Morte, gênero feminino (com M maiúsculo, que pode ser lido como dimensões dos vocábulos portugueses femininos "Maria" e "Mulher"), travestida em corpo de mulher, Saramago insere nas mãos do feminino o poder que a morte (com m minúsculo) tem sobre a vida. Noutras palavras, o escritor português engendra o feminino de duas dimensões: uma que ela já possui por natureza, a de mentora e constituinte da vida; outra, que aparentemente cabe apenas ao divino, que é o poder sobre esta vida. Nas malhas do texto, a Morte é quem desempenha o mesmo papel das outras personagens femininas dos dois últimos romances, Todos os nomes e A caverna, o de resgatar do marasmo a vida do homem.

Demarcadas estas linhas do feminino na obra saramaguiana estão estabelecidas também as vigas que dão sustentabilidade ao nosso estudo.

\section{O conto da ilha desconhecida}

O conto da ilha desconhecida, apresenta-nos apenas um fato que se desdobra em dois momentos na narrativa. O primeiro fato acontece de um homem que bate à porta do rei para pedir um barco, no intuito de encontrar uma ilha desconhecida. O segundo marca-se pela concessão do pedido, o sonho e a busca, marcados na tentativa de encontrar a ilha desconhecida.

O pedido tão simples que marca o primeiro momento do texto é o que desencadeia toda uma história sobre descobrimentos, conforme Gomide (2001, p.363), "sobre a possibilidade da criação e sobre a possibilidade do amor." A partir dos descobrimentos apontados na leitura da estudiosa em torno do conto, podemos falar do descobrimento do ser enquanto ser.

Se o pedido de um barco pode nos parecer simples, a aceitação dele nem tanto. Ainda mais quando o pedido é dirigido a um rei que, no auge da burocracia para atendê-lo, colocava todos os pedidos na mão da pessoa que ele achava mais insignificante, a da mulher da limpeza. Além disso, ocorre uma inversão de ordem, porque não era o rei quem pedia a um homem para procurar novas terras, como quando acontecia no período das navegações, mas um homem comum que quer um barco para descobrir o que era desconhecido inclusive para ele. 
O rei desconcertado com o pedido e com o apelo do povo às portas do palácio, resolveu ceder. Apresentou-se e a título de esconder-se da multidão, veio o mais humilde possível, recostou-se na cadeira da mulher da limpeza e discutiu o disparate:

\begin{abstract}
Que queres dizer, perguntou o rei, inquieto, Que tu, sem eles, és nada e que eles, sem ti, poderão sempre navegar, Às minhas ordens, com os meus pilotos e os meus marinheiros, Não te peço marinheiros nem piloto, só te peço um barco, E essa ilha desconhecida, se a encontrares, será para mim, A ti, rei, só te interessam as ilhas conhecidas, Também me interessam as desconhecidas quando deixam de o ser, Talvez esta não se deixe conhecer, Então não te dou o barco, Darás. (...) Perante uma tão iniludível manifestação da vontade popular e preocupado com o que, neste meio tempo, já haveria perdido na porta dos obséquios, o rei levantou a mão direita a impor silêncio e disse, Vou dar-te um barco, mas a tripulação terás de arranjá-la tu, os meus marinheiros são-me precisos para as ilhas conhecidas. (SARAMAGO, 1998, p.18-20).
\end{abstract}

A partir deste momento, o homem vai à doca, guiado por um cartão que deveria ser entregue ao capitão que lhe daria o barco despido de tripulação. Neste momento chega a mulher da limpeza, que, cansada do papel que sempre exerceu no palácio, resolve juntar-se ao homem na sua empreitada. O desejo de encontrar a ilha desconhecida passa a ser uno in duo; ela, assim como ele, queria descobrir e, tão segura deste desejo, saiu pela porta das decisões. A viagem em busca do desconhecido tem sua concretização aqui; é a partir deste momento que o desconhecido começa por ser descoberto. E é nessa empreitada que as dimensões do feminino se traçam.

Ao entendermos que nessa obra as personagens querem descobrir a si mesmas o sentido da sua existência, aqui cabe uma reflexão interessante concernente ao papel da mulher nas decisões e à representação de seu poder enquanto mulher. É ela que, pelo desejo do homem de busca pelo desconhecido, o encoraja a persistir na idéia. A mulher da limpeza se volta para o homem da ilha desconhecida como catalisadora de todo o processo de criação, consoante Gomide (2001, p.364-365): "Ela é a força que move o homem, já que o seu desejo se confunde com o dele. Inicialmente como mulher da limpeza do palácio, depois como porteira da utopia do homem e agora como parceira numa viagem ao desconhecido."

Neste conto a ação da mulher de juntar-se ao sonho do homem retoma o caráter feminino no qual acredita Saramago, o de que há nelas um sentido crítico instintivo, como que uma risonha compaixão, uma benevolência paciente (cf. BERRINI, 1998, p.240). Isto é, podemos entender o caráter que é incutido ao papel feminino como o de força mediadora à profícua realização da busca de autoconhecimento da personagem masculina. A mulher da limpeza parece cumprir a missão de quebrar a ótica pós-moderna, do individualismo do acúmulo de poder, das relações de manipulação dos sujeitos. Na cegueira branca que impossibilita ver no outro a si mesmo, a mulher da limpeza recobra a missão humana de unicidade, de divisão, de construir junto. 
O sonho da ilha desconhecida será um sonho para os dois, porque os marinheiros consultados, todos eles recusam a proposta de mergulho no desconhecido.

\section{Acerca das dimensões e tessituras do feminino em $O$ conto da ilha desconhecida}

Quando recobramos o fio narrativo d'O conto da ilha desconhecida, um acontecimento - o olhar da mulher da limpeza para o homem que queria o barco - encerra o existir da narrativa e do sonho. É esta imagem a primeira malha do tecido textual para com o feminino, é ela que dá forma, o princípio da consistência e a definição protocolar para conduzir a nossa possibilidade de leitura. Este encontro do masculino com o feminino é o que a faz mudar de rumo, sair pela porta das decisões:

Quando o homem levantou a cabeça, supõe-se que desta vez é que iria agradecer a dádiva, já o rei se tinha retirado, só estava a mulher da limpeza a olhar para ele com cara de caso. (...) A aldraba de bronze tornou a chamar a mulher da limpeza, mas a mulher da limpeza não está, deu a volta e saiu com o balde e a vassoura por outra porta, a das decisões, que é raro ser usada, mas quando o é, é. (SARAMAGO, 1998, p.23)

Também é a partir desse encontro que a viagem misteriosa em busca do desconhecido se delineia. Nesse percurso, a mulher da limpeza assume duas feições: a primeira se marca antes da viagem e de conhecer o homem que queria um barco. Nesta, precisava trabalhar de linha e agulha, na limpeza do palácio e de leva-e-traz para o rei, uma dimensão da insignificância que historicamente tem sido delegado ao sexo feminino. Aqui ela é um embrião do segundo sexo, comportando em si uma espécie de vazio de suas verdadeiras dimensões. $\mathrm{O}$ que lhes cumpre fazer diz respeito somente às tarefas domésticas, bem como a preencher o campo da submissão ao masculino: é ela a que atende a porta das petições, é ela a que oferece a cadeira de palhinha ao rei e é sobre seu ombro que o rei escreve a autorização para o homem adquirir o barco.

A saída pela porta das decisões simbolicamente denota a liberdade feminina. Como quando no movimento das décadas de 1960 e 1970 as mulheres francesas saíam às ruas de sutiã em punho, a mulher da limpeza sai de balde a vassoura na mão, num ato simbólico que assevera a submissão feminina ao trabalho doméstico.

A outra feição que a mulher da limpeza assume dá-se no processo dessa viagem em busca do desconhecido. Ainda que de balde e vassoura na mão para a limpeza do barco, a mulher antes de ser mulher, assume os ofícios maternos, de esposa, irmã, filha; ela possui algo fundamental que é a liberdade e a capacidade de optar, como quando acompanhada pelo homem que queria o barco escolhe o barco para viagem: 
O capitão do porto disse, Vou dar-te a embarcação que te convém, Qual é ela, É um barco com muita experiência, ainda do tempo que em toda a gente andava à procura de ilhas desconhecidas, Qual é ele, Julgo até que encontrou algumas, Qual, Aquele. Assim que a mulher da limpeza percebeu para onde o capitão apontava, saiu a correr de detrás dos bidões e gritou, É o meu barco, é o meu barco, há que perdoar-lhe a insólita reivindicação de propriedade, a todos os títulos abusiva, o barco era aquele de que ela tinha gostado, simplesmente. (SARAMAGO,1998, p.28)

Notemos ainda outro detalhe importante que a mulher carrega: o comedimento. Ainda que haja a transgressão ao colocar-se no papel masculino da escolha, ela ainda pede desculpas por isso, como prova de que essa fratura social pela qual o feminino escapa e funda outras dimensões não é um processo que ocorre num simples jogo de escolhas, mas através de fatores lentos da história social que emperram os carrilhões frouxos destas decisões.

Como na figura do mito cristão, a mulher da limpeza é Eva que, na coragem de abdicar da condição de mulher comum, tornando-se transgressora é capaz de guiar-se pelas trilhas do conhecimento, encantar o homem, e fundar nele a sua verdadeira outra dimensão; não acomodando na sua formação uma costela do homem, mas parte ao mesmo tempo presa e independente dele, uma espécie de bússola que inaugura no universo masculino a visibilidade das trilhas do conhecido para o desconhecido.

Ao ser aceita pelo homem que possuía o barco na empreitada utópica - "Sendo assim, vai para a caravela, vê como está aquilo, depois do tempo que passou deve precisar de uma boa lavagem, e tem cuidado com as gaivotas, que não são de fiar" (SARAMAGO, 1998, p.3132), a mulher da limpeza torna-se encarregada de todos os preparativos para a viagem. A imagem simbólica de bússola alarga-se e ela toma para a si os papéis sociais estritamente tidos como masculinos, como a arte da marinharia, cabendo-lhe o papel dos consertos do barco.

Após consultar os marinheiros acerca de sua empreitada em busca do desconhecido, o homem volta para o barco. Este movimento de retorno é o que dará outra dimensão ao feminino em sua tessitura, a de ouvinte desfeita em interlocutora.

Que pensas fazer, se te falta a tripulação, Ainda não sei, Podíamos ficar a viver aqui, eu oferecia-me para lavar os barcos que vêm à doca, e tu, E eu, Tens com certeza um mestre, um ofício, uma profissão, como agora se diz, Tenho, tive, terei se for preciso, mas preciso quero encontrar a ilha desconhecida, quero saber quem sou eu quando nela estiver, Não o sabes, Se não sais de ti, não chegas a saber quem és, O filósofo do rei, quando não tinha o que fazer, ia sentar-se ao pé de mim, a ver-me passajar as peúgas dos pajens, e às vezes dava-lhe para filosofar, dizia que todo homem é uma ilha, eu, como aquilo não era comigo, visto que sou mulher, não lhe dava importância, tu que achas, Que é necessário sair da ilha, que não nos vemos se não nos saímos de nós, Se não saímos de nós próprios, queres tu dizer (SARAMAGO, 1998, p.40-41) 
É neste diálogo que tomamos consciência daquele seu caráter de apenas ouvinte quando vivia no palácio. A partir deste diálogo, o seu caráter de feminino firma-se enquanto interlocutora. Destarte o papel feminino vai se moldando no corpo do texto e firmando-se enquanto sujeito ativo no processo da criação. Há uma subida hierárquica da mulher, definindo suas dimensões, que de porteira, encosto, passadeira, ouvinte vai se tornando guia, parceira e interlocutora. Ela cumpre o papel de, nesse movimento filosófico que o homem dá em torno de si mesmo, servir de ânimo, sopro, alento à frustração masculina.

Como ser que não se constitui sozinho pela necessidade de aprovação do outro, resta ao homem que tinha o barco ver a mulher na dimensão outra que contempla esta ausência. Isso, no entanto, só se dá no momento em que a mulher tira do bolso do avental dois pedaços de vela e acende-os. A magia metafórica que esta cena recobra em torno do feminino é única. Assinalam aqui o desejo da criação e o descobrimento dos dois enquanto prolongamentos que se encontram e se fazem uno. Este momento concretiza a dimensão final do feminino, em que sua alma arrancada de si emigra para o outro, remetendo diretamente ao mito do Gênese, em que Eva se constitui a partir da costela de Adão, num processo inverso, a constituição do homem enquanto ser pela ótica do feminino.

O encontro de ambos que se dá via sonho é quando se descobre a ilha desconhecida. Este encontro se dá por uma via dupla de sentido que se desdobra na tessitura final do feminino: numa vertente ideológica, a mulher da limpeza se constitui enquanto tal a partir do momento que se liberta das amarras sociais (a sua saída do palácio pela porta das decisões); numa vertente simbólica, ela é a dimensão outra, a complementaridade.

\footnotetext{
Acordou abraçado à mulher da limpeza, e ela a ele, confundidos os corpos, confundidos os beliches, que não se sabe se este é o de bombordo ou o de estibordo. Depois, mal acabou de nascer, o homem e a mulher foram pintar na proa do barco, de um lado e do outro, em letras brancas, o nome que ainda faltava dar-lhe à caravela. Pela hora do meio-dia, com a maré, A Ilha Desconhecida fez-se enfim ao mar, à procura de si mesma. (SARAMAGO, 1998, p.62)
}

Se a ilha desconhecida só passa a existir com a presença da mulher, o feminino é o escopo da criação, o mote onde o desejo do impossível se faz ver. É ela que leva o homem ao autoconhecimento, ressignificando-o e recompondo sua existência enquanto homem.

\section{Considerações finais}

Constituímos, assim, uma visão panorâmica para o feminino em $O$ conto da ilha desconhecida, suas dimensões e tessituras. Podemos afirmar que a mulher trilha uma subida 
hierárquica: de porteira, passadeira, encosto, ouvinte, se torna guia, parceira e interlocutora. $\mathrm{O}$ feminino é símbolo da criação ao mesmo tempo em que responsável por levar o homem ao autoconhecer-se, sendo dele uma extensão ou complementaridade, desempenhando o caráter formativo do masculino através da afetividade.

\section{Referências}

ARNAUT, Ana Paula. José Saramago: a literatura do desassossego. Disponível em: www.kufs.ac.jp/Brazil/03docentes/Arnaut.pdf. Último acesso em: 11 fev. 2007, p. 01-19.

GOMIDE, Maria de F. Itabirano. "Seja razoável, exija o impossível”: o sonho da ilha desconhecida. In: DUARTE, Lélia P; OLIVEIRA, Paulo Motta; OLIVEIRA, Silvana Maria Pessôa (orgs.). Anais do XVII Encontro de Professores Universitários Brasileiros de Literatura Portuguesa. vol. 1. FALE/UFMG e PUC-MG. Belo Horizonte, 2001, p. 363-367.

SARAMAGO, José. Ensaio sobre a cegueira. São Paulo: Companhia das Letras, 1995.

Entrevista com José Saramago. In: BERRINI, Beatriz. Ler Saramago: o romance. 2 ed. Editorial Caminho, 1998, p. 227-245.

. O conto da ilha desconhecida. 20 ed. São Paulo: Companhia das Letras, 1998.

SEIXO, Maria Alzira. Os espelhos virados para dentro - configurações narrativas do espaço e do imaginário em Ensaio sobre a cegueira In: Giulia Lanciani (org.) José Saramago - Il Bagaglio dello scrittore. Roma: Bulzoni Editore, 1996, p. 191-210. 